\title{
Cost Economics for Drying of Paddy Coupled with Gasifier
}

\author{
R. Swamy ${ }^{\text {* }}$, K. Sivala ${ }^{2}$, D. D. Smith ${ }^{3}$, K. Sadasivarao ${ }^{4}$ and R. Lakshimipathy ${ }^{5}$ \\ ${ }^{1}$ Department of Food Science and Technology, Rudrur, Nizamabad, India \\ ${ }^{2}$ Department of Food Science and Technology, Bapatla, India \\ ${ }^{3}$ Department of Food Science and Technology, Pulivendula, India \\ ${ }^{4}$ Department of Agricultural Engineering and Technology, PJTSAU, Rajendranagar, India \\ ${ }^{5}$ Department of Microbiology, APGC, Guntur, India \\ *Corresponding author
}

\section{A B S T R A C T}

Keywords

Gasifier, Dryer,

Repairs,

Maintenance cost,

Cost of raw

material, Present

conditions

Article Info

Accepted:

12 November 2019

Available Online:

10 December 2019
Harvested paddy grain with high moisture content must be dried to about 12 per cent (w.b) within 24 hours for safe storage and milling. Approximately 9 per cent of paddy was lost due to outdated drying methods, milling, unscientific method of storage, transport and handling (Basavaraj et al., 2015). Mechanical drying is essential to maintain the quality of grain during storage to prevent the growth of bacteria and fungi and the development of insects and mites. The economic feasibility of the on-farm paddy dryer coupled with a gasifier was analyzed by considering the initial investment of the gasifier, dryer, repairs and maintenance cost, cost of raw material. Present conditions, economic factors are the strongest augment for considering gasification for drying of paddy because the price of petroleum fuels is high. Break-even point for on-farm paddy dryer was calculated as 23.27 months. Benefit cost ratio for developed on-farm paddy dryer coupled with a gasifier was found to be 1.36 .

\section{Introduction}

Drying paddy is one of the major problems in India. Often grains become deteriorated due to improper drying which results in a poor germination. The use of mechanical drying is an alternative method to dry grains in order to assure good quality. Drying of paddy by other methods like hot air drying, dielectric energy and wood is expensive. Hence, drying by bioenergy through gasification process is economically a viable solution for drying high moisture content of paddy.

Kumar et al., (2009) reviewed the current status of use of thermochemical biomass 
gasification for producing biofuels, bio-power and chemicals. Biomass gasification is a promising technology to displace use of fossil fuels and to reduce $\mathrm{CO}_{2}$ emission.

Recently, the focus of its application has changed from production of combined heat and power to production of liquid transportation fuel. The challenges with gasification are to understand the effects of operating conditions on gasification reactions for reliable predictive and optimizing the product composition for obtaining maximal efficiencies.

Purohit (2009) studied economic potential of biomass gasification projects under clean development mechanism (CDM) in India. The results indicate that in India around 74 million tonne agricultural residues as a biomass feedstock can be used for energy applications on an annual basis.

\section{Cost of drying}

Drying cost is comprised of fixed costs and variable costs. Fixed cost includes depreciation, cost of interest, repair cost, and opportunity cost. Variable costs consist of fuel, labour and electricity costs. Depending on the purpose drying cost can be stated as either annual cost or cost per unit of weight.

Total drying costs are composed of two components, fixed cost and variable cost (IRRI, 2013).

$C_{D}=C_{F}+C_{V} \ldots(3.31)$

where,

$\mathrm{C}_{\mathrm{D}=}$ Total drying cost,

$\mathrm{C}_{\mathrm{F}}=$ Fixed cost,

$\mathrm{C}_{\mathrm{V}}=$ Variable cost,

\section{Variable costs}

The variable cost or operating cost mainly consists of the expenditure that only occur when the dryer was operated, namely fuel, electricity, labourcost and potentially other minor cost of items.

$C_{\text {var }}=C_{\text {fuel }}+C_{\text {electricity }}+C_{\text {labor }}+C V_{\text {others }}$

where,

$\mathrm{C}_{\mathrm{var}}=$ Variable cost,$₹ / \mathrm{t}$

$\mathrm{C}_{\text {Fuel }}$ Fuel cost, $₹ / \mathrm{t}$

\section{Fuel cost}

Cost of energy for the fuels used in the air heater was computed using the following equation

$c_{\text {fuel }}=\frac{F C \times c_{\text {fuel }}}{m_{\text {dry }}}$

where,

$\mathrm{C}_{f u e l}=$ Fuel cost, $₹ / \mathrm{t}$ of dried grain

$\mathrm{FC}=$ Fuel consumption, $\mathrm{kg} / \mathrm{batch}$

$c_{\text {fuel }}=$ Cost of fuel, ₹ $/ \mathrm{kg}$

$\mathrm{m}_{\mathrm{dry}}=$ Weight of dried grain per batch, $\mathrm{kg} / \mathrm{batch}$

\section{Electricity cost}

$C_{\text {electricity }}=\frac{P \times l f \times t_{o p} \times C_{k W h}}{m_{d r y}}$

where,

$C_{\text {electricity }}=$ Electricity cost, $₹ / \mathrm{t}$ 
$\mathrm{P}=$ Power rating of motor or component, $\mathrm{kW}$

$L f=$ Load factor, (usually 0.7 for motors)

$t_{\text {op }}=$ Operating time of component, h/batch

$C_{k W h}=$ Cost of one kWh electricity, $₹ / \mathrm{kWh}$

$\mathrm{m}_{\mathrm{dry}}=$ Weight of dry grain per batch, $\mathrm{t} / \mathrm{batch}$

\section{Fixed cost}

The fixed cost consists mainly of investment costs for a system and depends highly on dryer capacity, state of technology and local content.

$C_{f}=\frac{C_{\text {depr }}+C_{\text {repair }}+C_{\text {interest }}+C_{\text {others }}}{U}$

where, $=$

$\mathrm{C}_{\mathrm{F}}=$ Fixed cost, $₹ / \mathrm{t}$

$\mathrm{C}_{\text {depr }}=$ Annual depreciation, $₹ /$ year

$\mathrm{C}_{\text {repair }}=$ Annual repair cost, $₹ /$ year

$\mathrm{C}_{\text {interest }}=$ Annual interest cost, ₹ / year

$\mathrm{C}_{\text {others }}=$ Other annual cost, ₹ / year

$\mathrm{U}=$ Annual utilization, tonnes/year

\section{Depreciation}

For simplicity a linear depreciation is used. Usually a salvage value is used in the calculation of the depreciation but in many cases this is not realistic since dryers typically are used in one location until they fall apart.

$C_{\text {depr }}=\frac{C_{i n v}+S V}{E L}$

where,
$\mathrm{C}_{\mathrm{depr}}=$ Annual depreciation, $₹$

$\mathrm{C}_{\mathrm{inv}}=$ Investment cost, ₹

SV = Salvage value, $₹$

$\mathrm{EL}=$ Economic life, year

\section{Cost of interest}

The cost of interest averaged over the years was computed using the following equation

$C_{\text {int }}=\frac{C_{\text {inv }}}{2} \times \frac{R_{\text {int }}}{100}$

where,

$\mathrm{C}_{\mathrm{int}}=$ Annual cost interest, ₹ / year

$\mathrm{C}_{\text {inv }}$ Investment cost, ₹

$\mathrm{R}_{\text {int }}=$ Interest rate, $\%$

\section{Cost of repair}

A certain budget needs to be allocated to maintenance and repair needs. Based on manufactures recommendations this can be expressed in percentage of investment

$C_{\text {repair }}=\frac{C_{\text {inv }} \times R_{\text {repair }}}{100}$

where,

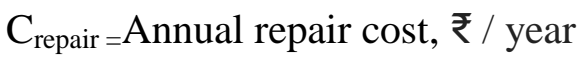

$\mathrm{C}_{\text {inv }}$ Investment cost, ₹

$\mathrm{R}_{\text {repair }}=$ Rate of repair in \% investment cost, \%

\section{Break-even point}

The break-even point in batches per year calculated as follows

$B E P=\frac{C_{i n v}}{\left(m_{\text {dry }} \times \Delta P\right)-C_{V}}$ 
where,

$\mathrm{BEP}=$ Break-even point per, batch $/$ year

$\mathrm{C}_{\mathrm{inv}}=$ Investment cost, ₹

$\mathrm{m}_{\mathrm{dry}}=$ weight of grain per batch after drying, $\mathrm{kg} / \mathrm{batch}$

$\Delta \mathrm{P}=$ Price difference of wet and dry grain, ₹ $/ \mathrm{kg}$

$\mathrm{C}_{\mathrm{v}}=$ Variable cost, $₹ / \mathrm{t}$

\section{Benefit-cost ratio}

The benefit-cost ratio (BCR) is the ratio of the gross benefits divided by the initial investment costs plus costs of operation.

For an investment worthwhile, BCR should be greater than one to indicate that the investor is recovering every worth of investment.

Conversely, a BCR lees than one implies that the assumed interest rate, the investment being evaluated is not profitable. The benefit-cost ratio is calculated as

$B C R=\frac{B_{\text {total }}}{C_{\text {total }} \ldots(3.40)}$

where,

$\mathrm{BCR}=$ Benefit-cost ratio

$B_{\text {total }}=$ Sum of discounted annual total benefit, ₹

$C_{\text {total }}=$ Sum of discounted annual total cost, ₹

\section{Results and Discussion}

Economic analysis of on-farm paddy dryer coupled with gasifier

Economic analysis of the system was estimated by annualized cost and life cycle savings. The life cycle saving of the system analysed for a total life span of 5 years. Table 1 comprises the data about the factors like the initial investment, salvage value annual savings, operating and maintenance cost, expected life of asset and annual cash benefit for the paddy dryer. Break-even point and benefit cost ratio for on-farm paddy dryer was calculated by considering total cost of operation which includes fixed cost and variable cost

\section{Break-even point}

Investment cost $=₹ .54425 .00$

weight of dried grain $=0.890 \mathrm{t} / \mathrm{batch}$

Price difference of wet and dry grain $=₹$. $3.25 \mathrm{~kg}^{-1}$

Variable cost $=₹ .554 .00 \mathrm{t}^{-1}$

$B E P=\frac{54425.00}{890 \times 3.25-554.00}$

$=23.27$ months

\section{Benefit-cost ratio}

The benefit-cost ratio (BCR) is the ratio of the gross benefits divided by the initial investment costs plus costs of operation. The benefit-cost ratio is calculated as

Gross benefits $=₹ .1,06,241.52$

Initial investment costs plus costs of operation

$=₹ .77,749.00$

$B C R=\frac{106241.52}{77,749.00}$

$=1.36$ 
Table.1 Total operational cost of on-farm paddy dryer

\begin{tabular}{|c|c|c|c|}
\hline \multicolumn{4}{|c|}{ I. $\quad$ Fixed cost } \\
\hline & a) Depreciation Cost & & \\
\hline & Investment cost & $=$ & ₹. 54425.00 \\
\hline & $\begin{array}{l}\text { Salvage value @ } \\
10 \% \text { of Investment cost }\end{array}$ & $=$ & $₹ .5442 .50$ \\
\hline & Economic life & $=$ & 5 years \\
\hline & Sub total & $=$ & ₹. 11973.50 peryear \\
\hline \multicolumn{4}{|c|}{ b) Repair cost } \\
\hline & Investment cost & $=$ & $₹ .54425 .00$ \\
\hline & $\begin{array}{l}\text { Rate of repair @ } \\
10 \% \text { of Investment cost per year }\end{array}$ & $=$ & ₹ $5442.50 ₹$ \\
\hline & Sub total & $=$ & ₹. 5442.50 per year \\
\hline \multicolumn{4}{|c|}{ c) Cost of interest } \\
\hline & Investment cost & $=$ & $₹ .54425 .00$ \\
\hline & $\begin{array}{l}\text { Rate of interest @ } \\
16 \% \text { of investment cost year }\end{array}$ & $=$ & $₹ 8708.00$ \\
\hline & Sub total & $=$ & ₹. 4354.00 per year \\
\hline & Fixed cost total & $=$ & ₹. $21,770.00$ \\
\hline \multicolumn{4}{|c|}{ Variable cost } \\
\hline & a) Fuel cost & & \\
\hline & Fuel consumption & $=$ & 12 kg batch-1 \\
\hline & Cost of fuel & $=$ & ₹. $4.00 \mathrm{~kg}-1$ \\
\hline & Weight of dried grain & $=$ & $0.890 \mathrm{t}$ batch-1 \\
\hline & Sub total & $=$ & ₹. $54.00 \mathrm{t}-1$ \\
\hline & b) Electricity cost & & \\
\hline & Power required & $=$ & $2.237 \mathrm{~kW}$ \\
\hline & Load factor & $=$ & 0.7 \\
\hline & Operating time & $=$ & $8 \mathrm{~h} / \mathrm{batch}$ \\
\hline & Cost of one kWh electricity, & $=$ & $₹ .1 .45$ per $\mathrm{kWh}$ \\
\hline & Weight of dry grain per batch, & $=$ & $0.890 \mathrm{t}$ batch -1 \\
\hline & Sub total & $=$ & ₹. $20.00 \mathrm{t}-1$ \\
\hline & c) Labour cost & & \\
\hline & $\begin{array}{l}\text { Labour requirement for loading and } \\
\text { unloading @ } 1 \text { man day/batch }\end{array}$ & $=$ & ₹. 400.00 \\
\hline & $\begin{array}{l}\text { Labour requirement for drying @ } 0.2 \\
\text { man day/batch }\end{array}$ & $=$ & ₹. 80.00 \\
\hline & Sub total & $=$ & ₹. 480.00 per batch \\
\hline & Variable cost total & $=$ & ₹. 554.00 \\
\hline Grand to & tal cost $($ Fixed + Variable cost $)$ & $=$ & $₹ .22324 .00$ \\
\hline
\end{tabular}


Economic analysis based on benefit-cost ratio

Cost of on-farm paddy dryer coupled with a gasifier benefit cost ratio was 1.36 . It was considered that the on-farm paddy dryer coupled with a gasifier adoption is economically viable in addition to environmental benefits.

Due to its cost effectiveness, the paddy dryer can play vital role in bringing sustainable energy to the paddy farmers in rural community of India. Gasifier assisted paddy dryer can be proposed as a suitable alternative to mechanical dryers.

Harvested paddy grain with high moisture content must be dried to about 12 per cent (w.b) within 24 hours for safe storage and milling. Approximately 9 per cent of paddy was lost due to outdated drying methods. The economic feasibility of the on-farm paddy dryer coupled with a gasifier was analysed by considering the initial investment of the gasifier, dryer, repairs and maintenance cost, cost of raw material Break-even point for onfarm paddy dryer was calculated as 23.27 months. Benefit cost ratio for developed onfarm paddy dryer coupled with a gasifier was found to be 1.36 . Hence, gasifier adoption is economically viable

\section{References}

Anonymous, 2015. Annual report 2014-15, Department of Agriculture and cooperation, Ministry of Agriculture, Government of India.

Basvaraj, Ravireja, G., Srinivas, D., Ramappa, K.T and Sharanagouda, H. 2015. Compartive study of manual and mechanical rice puffing methods. International Journal of Agricultural Science and Research. 5(5): 209-216

FAOSTAT, 2017. Food and Agriculture Organization of the United Nations

Kumar, A., Jones, D.D and Hanna, M. A. 2009. Thermo chemical biomass gasification: a review of the current status of the technology.Energies.2: 556-581.

Purohit, P. 2009. Economic potential of biomass gasification projects under clean development mechanism in India. Journal of Cleaner Production. 17: 181-193.

IRRI, 2013. Training Manual Paddy Drying. Post harvest unit. CESD. Version 2

\section{How to cite this article:}

Swamy, R., K. Sivala, D. D. Smith, K. Sadasivarao and Lakshimipathy, R. 2019. Cost Economics for Drying of Paddy Coupled with Gasifier. Int.J.Curr.Microbiol.App.Sci. 8(12): 1623-1628. doi: https://doi.org/10.20546/ijcmas.2019.812.195 